Abstracta Iranicacta Iranica

Revue bibliographique pour le domaine irano-aryen

Volume 28 | 2007

Comptes rendus des publications de 2005

\title{
Ṭarz-e tāze-ye sabk-šenāsī-ye ġazal-e sabk-e hendī. Tehrān, SoḤan, 1384/2005, 272 p.
}

\author{
Aftandil S. Erkinov
}

\section{(2) OpenEdition}

\section{Journals}

\section{Édition électronique}

URL : http://journals.openedition.org/abstractairanica/20811

DOI : 10.4000/abstractairanica.20811

ISSN : 1961-960X

Éditeur:

CNRS (UMR 7528 Mondes iraniens et indiens), Éditions de l'IFRI

Édition imprimée

Date de publication : 15 mai 2007

ISSN : 0240-8910

Référence électronique

Aftandil S. Erkinov, «Ṭarz-e tāze-ye sabk-šenāsī-ye ġazal-e sabk-e hendī. Tehrān, Sohan, 1384/2005, 272 p. », Abstracta Iranica [En ligne], Volume 28 | 2007, document 337, mis en ligne le 18 septembre 2007, consulté le 25 septembre 2020. URL : http://journals.openedition.org/abstractairanica/20811 DOI : https://doi.org/10.4000/abstractairanica.20811

Ce document a été généré automatiquement le 25 septembre 2020.

Tous droits réservés 


\title{
Ṭarz-e tāze-ye sabk-šenāsī-ye ġazal- e sabk-e hendī. Tehrān, SoH̆an, 1384/2005, $272 \mathrm{p}$.
}

\author{
Aftandil S. Erkinov
}

1 This book focuses on the analysis of the Indian style in Persian poetry. Particular attention is paid to following poets: 'Abd al-Raḥmān Jāmī, Bābā Faġānī, Naẓīī Nīšāpūrī, 'Orfî Šīrāzì, Ẓohūrī Toršīzī, Ṭāleb Āmolī, Kalīm Kāšānī, Sā’eb Tabrīzī. Among them, 'Abd al-Raḥmān Jāmī is cited, although he did not use the Indian style he played a very important role in Persian poetry. During the centuries that followed, all Persian poetry was directly inluenced by his creativity and knowledge. The author studies each poet's poetry from two points of view: the language and the poetic style of the poet. It means that in the book, the place of the Indian poetic style in the poetry of each of the abovementioned poets is studied, as well as the ways Indian style is expressed in their creations. Each time the author analyzes the Indian poetic style in the works of a poet, using the parameters mentioned above, he searches for the most characteristic features in the poet's heritage. For example, the part of the research where language is studied focuses on the simplicity of language (Bābā Faḡānī) and the use of popular words (Nazīini Nī̌̄āpūrī, Ẓohūrī Toršīzī, Ṭāleb Āmolī). The analysis of the poetic styles involves tekrār-e qāfiye - repetition of a rhyme (Kalīm Kāšānī, Sā’eb Tabrīzī) and others.

\section{INDEX}

Thèmes : 11.1.1. Littérature persane classique 


\section{AUTEURS}

AFTANDIL S. ERKINOV

Université nationale de l'Ouzbékistan - Tachkent 